\title{
Indian scientists battle journal retraction
}

\section{BANGALORE}

A high-profile case in India continues to escalate. A government committee has cleared a top cancer researcher and his group of wrongdoing after a US journal retracted their paper over charges of data manipulation. But India's ethics watchdog, the New Delhi-based Society for Scientific Values (SSV), charges the committee with "possible complicity" in attempting to save the reputation of an award-winning scientist and the image of a prominent government research institute.

The arguments centre on a 2005 paper in the Journal of Biological Chemistry $(J B C)$, which examined signalling pathways in the development of skin cancer (Rangaswami, H., Bulbule, A. \& Kundu, G. C. J. Biol. Chem. 280, 19381-19392; 2005). It was

\section{"Our detailed} investigation shows there was no manipulation." of the 100 or so blots in the papers - did not affect the conclusions in any way," adds first author Hema Rangaswami, now a postdoc at the University of California in San Diego. "We feel $J B C$ 's decision to withdraw our paper was totally unfair." But Shelagh Ferguson-Miller, chair of the publications committee for the journal's publisher, says that it does not plan to reconsider the paper's withdrawal.

A seven-member committee, set up by the Department of Biotechnology, which oversees the NCCS, appears to back up Rangaswami's claims. In its 30 May report, the committee said the allegations were baseless. "Our detailed investigation shows there was no manipulation," says Govindarajan Padmanabhan, chairman of the committee. He adds that the journal did not analyse the researchers' raw data, but instead relied on image analysis of published figures. Padmanabhan says the committee plans to appeal to the journal to rescind the withdrawal.

But the SSV claims its own findings, released on 28 April, suggested that the group fabricated images in the second paper from blots in the first paper. Sohan Modak, a former member of the centre's governing council and whose complaint launched the SSV investigation, says he remains convinced the images are the same.

The jury may still be still out, but Kundu has already paid a price. His nomination to the fellowship of the Indian National Science Academy has been held up. And Rangaswami's $\mathrm{PhD}$ hangs in the balance: she has not yet been called to defend her thesis at Pune University.

\section{K. S. Jayaraman}

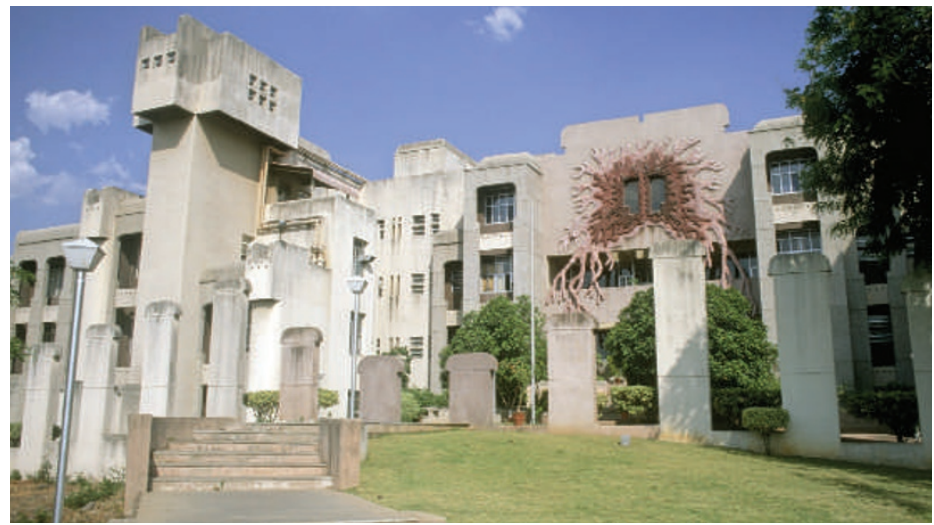

Reputation on the line?: the National Centre for Cell Science in Pune, India. 